\title{
INTERACTION BETWEEN KILLER WHALES (ORCINUS ORCA) AND HAMMERHEAD SHARKS (SPHYRNA SP.) IN GALÁPAgOS WATERS
}

\author{
Luca Sonnino Sorisio ${ }^{1}$, Alessandro De Maddalena² and Ingrid N. VisSer ${ }^{3,4}$
}

\begin{abstract}
Aвstract: A possible predatory interaction between killer whales (Orcinus orca) and hammerhead sharks (Sphyrna sp.) was observed during April 1991 near Punta Cormorant, Galápagos Islands. Three killer whales were observed in close proximity to a freshly dead female hammerhead. One of the killer whales (approximately $6 \mathrm{~m}$ in length) was observed motionless in a vertical position above the shark carcass and later was seen chasing an approximately $40 \mathrm{~cm}$ hammerhead, supposedly a pup born prematurely from the dead shark. The sharks are thought to have been scalloped hammerheads (S. lewini).

ResúmEN: Una posible interacción predatoria entre orcas (Orcinus orca) y peces martillo (Sphyrna sp.) fue observada en Abril de 1991 cerca de Punta Cormorán, Islas Galápagos. Tres orcas fueron vistas muy próximas a una hembra de pez martillo recién muerta. Una de las orcas (de unos $6 \mathrm{~m}$ de longitud), fue observada inmóvil en posición vertical sobre la carcasa del tiburón y después fue vista persiguiendo a un pez martillo de unos $40 \mathrm{~cm}$, supuestamente una cría nacida prematuramente de la hembra muerta. Se piensa que los tiburones pudieran ser cornudas negras (S. lewini).
\end{abstract}

KEYwORDs: killer whale; Orcinus orca; hammerhead shark; Sphyrna; predation.

Observations of killer whales (Orcinus orca) feeding on, or attacking sharks are relatively infrequent (Table 1 ). Reports of killer whales off the Galápagos Islands are not common (e.g., Day, 1994; Merlen, 1999; Smith and Whitehead, 1999) as during a 27-year period of record keeping (1973-2000) only 38 records have been collated (Palacios, 2002 in Palacios et al., 2004). Although cetacean strandings and remains have been well documented from the area (Palacios et al., 2004), there are no records of killer whales stranding or being beach-cast onto the Galápagos Islands. There are only two published accounts of killer whale predation on sharks in this area, including a Galápagos shark (Fertl et al., 1996) and an unidentified hammerhead shark (Merlen, 1999). Given the infrequent sightings and even rarer number of observations of killer whale predation off the Galápagos Islands, we report here on a possible predatory interaction between killer whales and hammerhead sharks (Sphyrna sp.).

During April 1991, as part of a photo-journalistic expedition of the Galápagos Islands (Ecuador) (Sonnino Sorisio, 1991), one of the authors (LSS) was aboard a $22.5 \mathrm{~m}$ motor yacht, the Mistral. The observations reported here were made near Punta Cormorant, Floreanea Island $\left(01^{\circ} 18^{\prime} \mathrm{S}, 90^{\circ} 27^{\prime} \mathrm{W}\right)$. Surface and underwater (snorkeling) observations were made during favourable conditions (Beaufort Sea State 1 , sunlight and approximately $15 \mathrm{~m}$ visibility).

Table 1. Published accounts of killer whales feeding on or attacking sharks (where species are known).

\begin{tabular}{ll}
\hline \hline SPECIES & \multicolumn{1}{c}{ SOURCE } \\
\hline \hline Sevengill shark (Notorynchus cepedianus) & Reyes and García-Borboroglu (2004) \\
School shark (Galeorhinus galeus) & Visser (2000a) \\
Whale shark (Rhincodon typus) & Fertl et al. (1996) \\
Common thresher shark (Alopias vulpinus) & Visser (2005) \\
Basking shark (Cetorhinus maximus) & Brown and Norris (1956); Norris (1958); Yukhov et al. \\
& (1975); Fertl et al. (1996); Visser (2000b, 2005) \\
Great white shark (Carcharodon carcharias) & Pyle et al. (1999) \\
Grey reef shark (Carcharhinus amblyrhynchos) & Visser and Bonaccorso (2003) \\
Galápagos shark (Carcharhinus galapagensis) & Fertl et al. (1996) \\
Shortfin mako (Isurus oxyrinchus) & Visser et al. (2000) \\
Blue shark (Prionace glauca) & Ternullo et al. (1993); Fertl et al. (1996); Visser (2000b, 2005) \\
Scalloped hammerhead shark (Sphyrna lewini) & Visser and Bonaccorso (2003) \\
Smooth-hammerhead (Sphyrna zygaena) & Visser (2005) \\
\hline \hline
\end{tabular}

\footnotetext{
${ }^{1}$ Via Tevere 44, I-00198, Roma, Italy.

${ }^{2}$ Italian Great White Shark Data Bank, via L. Ariosto 4, I-20145, Milano, Italy. E-mail: a-demaddalena@tiscali.it.

${ }^{3}$ Orca Research Trust, 754 Matapouri Road, RD 3, Whangarei, 0121, New Zealand. Email: ingrid@orca.org.nz.

${ }^{4}$ Earth \& Oceanic Sciences Research Institute, Auckland University of Technology, Private Bag 92006, Auckland 1020, New Zealand.
} 
Whilst the Mistral was anchored west of Punta Cormorant, a killer whale approximately $6 \mathrm{~m}$ in length, compared to the size of the vessel, raised its head out of the water and appeared to investigate and then swim around the motor yacht. Approximately one minute later, it swam towards a point about $100 \mathrm{~m}$ from the Mistral, where other two similarly-sized killer whales were observed surfacing. Based on size alone, it was not possible to determine if any of the whales were male or female (sub-adult males are a similar size to adult females), however they were clearly not adult males as they all lacked large pectoral fins, curled tail flukes and tall dorsal fins (see Bigg, 1982 for full descriptions of sexual dimorphism in killer whales).

The killer whales swam in close proximity (approximately one body length) to one another. Seabirds, including boobies (Sula sp.), frigatebirds (Fregata sp.) and brown pelicans (Pelecanus occidentalis) were observed circling above the whales. LSS and others from the Mistral boarded a smaller boat used as a tender and moved towards the killer whales, that were approximately $100 \mathrm{~m}$ offshore, and had already split into two groups comprised of two and one animals, respectively.

When approximately $10-15 \mathrm{~m}$ from the single killer whale, LSS and two others entered the water, leaving people on the boat. A dead female hammerhead shark could be clearly seen lying on the sandy bottom. It was estimated to be 2.5-3m long, compared to the size of the killer whale hovering approximately $3 \mathrm{~m}$ directly above it. The whale was motionless, in a vertical position, with its rostrum oriented towards the shark. The shark was entire, and showed no visible signs of bites or external wounds.

After approximately one minute, the killer whale began moving towards the shark lying on the bottom. The divers moved closer to attempt to identify the shark species and noticed that the killer whale had begun to chase a small (approximately $40 \mathrm{~cm}$ ) hammerhead shark. Although the small shark appeared disoriented, was swimming lethargically and did not appear to avoid the killer whale, the whale made little effort to catch and eat it. After only a few minutes, the killer whale, whilst continuing to pursue the small hammerhead shark, swam out of visibility range. Whilst the divers were observing the killer whale underwater, the tender followed the two other killer whales, approximately $100 \mathrm{~m}$ from the dead shark and the divers.

In the meantime, the divers saw two Galápagos sea lions (Zalophus californianus wollebaeki) swimming rapidly and in apparent random directions, but near the bottom. The single killer whale the divers had previously been watching reappeared without the smaller hammerhead shark and moved towards the divers. The killer whale ignored the sea lions that continued to swim rapidly in the general area. As the killer whale moved towards the divers, they, unsure of its intentions, moved together into a tight group. When the whale was $10 \mathrm{~m}$ from the divers it turned away and swam out of visibility range. During the entire encounter, which lasted a few minutes in total, only one killer whale was observed underwater. As far as could be ascertained the killer whales took no further notice of the female shark, lying dead on the bottom.

The three killer whales were then observed from the tender, surfacing together once, heading north and were not seen again. Whilst in the tender and returning to the Mistral, the fresh carcass of a young Galápagos sea lion was observed floating at the surface with no evident external wounds.

We believe the event reported here might represent an attack on a hammerhead shark, and as such it would be only the fourth published on any of the hammerhead species, following those reported by Skinner (1994) ${ }^{5}$, Merlen (1999), Visser and Bonaccorso (2003) and Visser (2005).

At least three species of hammerhead sharks occur in Galápagos waters; scalloped, smooth and great ( $S$. mokarran) (Compagno et al., 1984), but other species are possibly present (bonnethead S. tiburo, scalloped bonnethead S. corona and scoophead S. media) (Compagno et al., 1984). With regard to the $2.5-3 \mathrm{~m}$ dead shark reported here, the large size excludes bonnethead, scalloped bonnethead, and scoophead hammerhead sharks, as none of these species exceeds $150 \mathrm{~cm}$ in length (Compagno et al., 2005). However, its size falls into the average size for sexually mature female scalloped, smooth and great hammerhead sharks; and the size of the small $(40 \mathrm{~cm})$ free-swimming specimen is consistent with a near-term embryo of these species (based repectively on size at maturity and at birth in Compagno et al., 2005). Although identification to species, based on the underwater observations and photographs was not possible, the commonest hammerhead species in the Galápagos Islands area is the scalloped (schools of up to hundreds of individuals are regularly observed in these waters, J. Bird, pers. comm.) and this, along with the estimated sizes, suggests that the sharks were most likely scalloped hammerheads.

Tortonese (1956) reported that sharks often give birth during times of stress, such as when entangled in nets or when caught on lines. Scalloped hammerhead sharks are placental viviparous, i.e., are born alive and fully functioning (Compagno et al., 2005). Therefore, given the small size of the live hammerhead observed here, its proximity to the large female, and its apparent disorientation and lethargic swimming, it is probable that it was born prematurely or near full-term, during the death, or shortly after, of the female shark. 
Given the observations of both the dead sea lion and female shark which had no external wounds, it is probable this event was not a feeding attack. Additionally, none of the killer whales were observed feeding on the sea lion or female shark, nor did the single killer whale appear intent on eating the newborn. However, these may have been training, practice or play mortalities. Futhermore, it cannot be ruled out that the shark died during parturition and the killer whales came across the carcass and aborted young, and were curious.

Regardless, by reporting events such as the one here, we hope to encourage further investigations to establish how rare such cases are in the Galápagos area, and help to understand sources of natural mortality for Galápagos elasmobranchs.

\section{Acknowledgments}

Thanks to all those who offered their help in preparing this work: Irene Martini, Gabriela Cardenas Diana, Dolores De Diez, Geoff Skinner, Jonathan Bird, Alex Buttigieg, Joan Barrull and Isabel Mate. We also thank Karen Stockin, Malcolm Francis and the anonymous reviewers for their helpful comments. A particular thanks from ADM to his wife Alessandra and his son Antonio. INV is supported by the Orca Research Trust, Yamaha Marine (NZ) and the Whale and Dolphin Conservation Society.

\section{References}

BIGG, M.A. (1982) An assessment of killer whale (Orcinus orca) stocks off Vancouver Island, British Columbia. Reports of the International Whaling Commission 32:655-666.

BROWN, D.H. AND NorRIS, K.S. (1956) Observations of captive and wild cetaceans. Journal of Mammalogy 37(3): 311-326.

Compagno, L. J. V. (1984) FAO species catalogue. Vol. 4. Sharks of the world. Part 2. Carcharhiniformes. Fisheries Synopsis, 125. FAO, Rome, Italy.

Compagno, L., Dando, M. And Fowler, S. (2005) Sharks of the World. Princeton University Press, Princeton, NJ, USA, 480pp.

DAY, D. (1994) List of cetaceans seen in Galàpagos. Noticias de Galàpagos 53(5): 5-6.

Fertl, D., Acevedo-Gutiérrez, A. And Darby, F.L. (1996) A report of killer whales (Orcinus orca) feeding on a carcharhinid shark in Costa Rica. Marine Mammal Science 12(4): 606-611.
MerLen, G. (1999) The orca in the Galápagos: 135 sightings. Noticias de Galápagos 60(December): 1-9.

NorRIS, K.S. (1958) Facts and tales about killer whales. Pacific Discovery (January): 24-27.

Palacios, D.M., Salazar, S.K. and Day, D. (2004) Cetacean remains and strandings in the Galápagos Islands, 1923-2003. Latin American Journal of Aquatic Mammals 3(2): 127-150.

Pyle, P., Schramm, M.J., Keiper, C. And Anderson, S.D. (1999) Predation on a white shark (Carcharodon carcharias) by a killer whale (Orcinus orca) and a possible case of competitive displacement. Marine Mammal Science 15(2): 563-568.

Reyes, L.M. and García-Borboroglu, P. (2004) Killer whale (Orcinus orca) predation on sharks in Patagonia, Argentina: A first report. Aquatic Mammals 30(3): 376-379.

Smith, D.S. and Whitehead, H. (1999) Distribution of dolphins in Galápagos waters. Marine Mammal Science 15(2): 550-555.

SonNino Sorisio, L. (1991) Alle Galapagos sulla scia della Beagle. Nautica 355: 302-313.

Tortonese, E. (1956) Fauna d'Italia Vol.II. Leptocardia, Ciclostomata, Selachii. Calderini, Bologna, Italy. 334pp.

VISSER, I.N. (1999) Benthic foraging on stingrays by killer whales (Orcinus orca) in New Zealand waters. Marine Mammal Science 15(1): 220-227.

VISSER, I.N. (2000a) Killer whale (Orcinus orca) interactions with longlines fisheries in New Zealand waters. Aquatic Mammals 26(3): 241-252.

VISSER, I.N. (2000b) Orca (Orcinus orca) in New Zealand waters. Ph.D. dissertation, University of Auckland, Auckland, New Zealand. 194pp.

VISSER, I.N. (2005) First observations of feeding on thresher (Alopias vulpinus) and hammerhead (Sphyrna zygaena) sharks by killer whales (Orcinus orca), which specialise on elasmobranchs as prey. Aquatic Mammals 31(1): 83-88.

VISSER, I.N. AND BONACCORSO, F.J. (2003) New observations and a review of killer whale (Orcinus orca) sightings in Papua New Guinea waters. Aquatic Mammals 29(1): 150-172.

Visser, I.N., Fertl, D., Berghan, J. AND VAn Meurs, R. (2000) Killer whale (Orcinus orca) predation on a shortfin mako shark (Isurus oxyrinchus), in New Zealand waters. Aquatic Mammals 26(3): 229-231.

Yukhov, V.L., Vinogradova, E.K. And MedvedeV, L.P. (1975) Ob'ekty pitaniya kosatok (Orcinus orca L.) v Antarktike i sopredel'nykh vodakh [The diet of killer whales (Orcinus orca L.) in the Antarctic and adjacent waters]. Pages 183-185 in Agarkov, E.G. (Ed.) Morskie mlekopitayushchie [Marine Mammals]. Naukova Dumka, Kiev. 